\title{
A Right, Not a Privilege: Gayatri Chakravorty Spivak’s An Aesthetic Education in the Era of Globalization
}

\author{
Joylette Williams Samuels \\ Nassau Community College, State University of New York, United States
}

\begin{abstract}
Gayatri Spivak proposes that providing all citizens throughout the Middle East and North Africa with an aesthetic education will enhance the quality of life for all people of the region, especially women. She argues that an education in the humanities is vital for improving the environment, the political climate, the economy, and for increasing global justice.
\end{abstract}

Keywords: postcolonialism, feminism, higher education, humanities, human rights

\section{Introduction}

Many of the essays in An Aesthetic Education in the Era of Globalization were written before what has come to be known as the Middle Eastern Spring of 2011, however, the analysis Gayatri Spivak offers of the post 9/11 political, economic, and cultural climate is crucial in examining the progress of Tunisia, Egypt, Syria, Yemen, and Libya since the resistance that had been ongoing for years erupted in a series of protests. Spivak foreshadows the far-reaching effects of education in the arts, sciences, and humanities for the cultural and economic transformations that societies throughout the Middle East and North Africa are currently experiencing as a result of an emphasis on basic access to education for women and girls as well as study within the aesthetics. These countries in the process of political and cultural transition, Spivak would argue, are "states where welfare is being eroded because national capital is supposed to be continuous with international capital in globalization” (2012, p. 468).

\section{The Humanities-Globalization Connection}

The study of arts and humanities has far-reaching outcomes for environmental, technological, economic, political, and social advancements, especially throughout the global South. Spivak eloquently argues that "aesthetic education is the last available instrument for implementing global justice and democracy", and subsequently the quality of life will increase in the Arab world when holistic education includes a sense of empowerment inspired by a study of the humanities (2012, p. 2). Given the emphasis on the United Nation's Millennium Development Goals, first published in 2000, Spivak’s words are prophetic. ${ }^{1}$ She theorizes that there is an inherent connection between the curriculum and environment, politics, human rights, and economic development. Furthermore, cultural politics will also evolve so that the human rights climate will increase as well. Studying aesthetics would, in a sense, bring wholeness to a new form of education within an emerging

\footnotetext{
Joylette Williams Samuels, Associate Professor of English, Women’s Studies, and Human Rights Studies, Nassau Community College, State University of New York.

${ }^{1}$ See from http://www.Un.org/millenniumgoals/2015_MDG_Report.
} 
new consciousness, especially for impoverished populations. Globalism will, in turn, expand in accordance as each society embraces a more democratic curriculum.

\section{Aesthetic Education and Feminism}

Spivak's notion of the relationship between an aesthetic education and one's quality of life is inherently feminist in nature. Spivak takes on the idea of multicultural rights which, on some level, is at the epitome of the idea that an aesthetic education should be available to all people regardless of race, nationality, or the political climate of one's environment. She writes that,

The construction of the postcolonial subject was to code the failure of decolonization as multiculturalism, in metropolitan space, to race, itself rewritten as a fantasmatic national identity as its subject. So if the first was class, the second is race as multiculture-cultural rights. Identitarian politics succeeds insofar as class and gender remain subsumed to this notion of a national and postnational identity. The construction, on the other hand, of the globalized subject is through the manufacturing of a gender alliance. The female subject/agent of globalization often collectively legitimizes itself in the name of a generalized ethical agenda. This is where she crosses the capital/culture aporia on the side of capital. Yet to work for global justice as a principle is as right a decision as to work for strategy-driven globalization. (2012, pp. 105-106)

In order for women to participate on the global scale as contributors to economic stability, knowledge of investment strategies is crucial. However, Spivak is suggesting a notion here that is greater than merely indicating the positive effects of women participating in a globalized economy. Underlying her argument is an acknowledgement of the necessity of an aesthetic education that promotes the critical thinking and analytical skills necessary to establish and maintain the intellectual capital that is needed to increase women's economic influence on a global scale. Ultimately, this same level of academic preparation is essential in sustaining the movements throughout the Middle East that gained momentum during the 2011 and 2012 uprisings which, hopefully, will now lead to governmental cabinets that hold themselves accountable for the livelihoods of an empowered people who will no longer accept corrupt practices that do not improve living conditions across the board, and especially one that provides a better quality of life for people of the lower socioeconomic classes.

Spivak also elaborates on the significance of women's roles in society through both image and social class. Western influences continue to conflict with the ideals of religion-based cultures within Islamic countries, especially for younger school-aged generations using the Internet and social media, which was a major factor in the success of the protests in Tahrir Square. James Gelvin observes that,

Social media performed two functions in the uprisings: they facilitated communication among the participants and would-be participants who elected to take part in the protests, and they broadened the range of tactical options (such as organizing demonstrations in “real time,” for example) open to those participants. (2012, p. 2)

Thus, the high school and college-aged participants in the uprisings embraced modern forms of communication that caused the movements to be more effective. This is also the population Spivak is referring to in her examination of aesthetic education and evolving political climates throughout the Middle East. In a chapter entitled, “The Double Bind Starts to Kick In”, Spivak opens the chapter by asking herself, "How is it possible to reconcile what I learn in the field with what I teach for a living?” (2012, p. 97). To this question, there is also an interrogation of the role of parental influence and religious values within the holistic educational experience of the next generation that is emerging amidst governmental restructuring as a result of the Arab Spring. While the biological role of "mother" in its most traditional sense is a celebrated and honored 
position within the Islamic family structure that predominates in the Arab world, the influence of non-biological "other mothers" that foster the intellectual, spiritual, and socially-committed community cannot be overlooked. In fact, Gayatri Spivak herself is known throughout academia as the "Mother of Postcolonial Theory and Criticism"! While formal education is an essential factor in the sustainability of a viable government, the sense of empowerment that a child learns at home is just as necessary and goes hand-in-hand with the aesthetic education of the child in his or her academic life. The appropriateness of Spivak's initial question can be applied to many aspects of the larger question of how to train the next generation of political leaders to a more sustainable government in the Middle East and North Africa.

To the extent that this region will be emerging as a political force in the global North once the governments begin to stabilize, Spivak’s next point of departure regarding women is equally as important for her overall conflict of the "double bind”. She writes,

Modernization was international. Postmodernization is global. The boundaries of nation-states are now increasingly inconvenient, yet must be reckoned with, because the limits and openings of a particular civil society are state-fixed. The globalization of capital requires a post-state system. The use of women in its establishment is the universalization of feminism of which the United Nations is increasingly becoming the instrument. (2012, p. 100)

If feminism is taking on this role with an ever-growing presence, there is no reason to assume women cannot play a crucial role in the further development of improving the quality of their lives throughout countries such as Egypt and Syria on every level.

\section{Societies in Transition: The Transformative Influence of Aesthetics}

With increased strategies in providing access to basic education for women and girls throughout the Middle East and North Africa, public policy is under scrutiny on a global scale more than ever. Larger than the idea of feminism itself, Gayatri Spivak clarifies her position on the transformative effects of an aesthetic education even before the current educational crisis received international attention as number three of the eight Millennium Development Goals proclaimed by the United Nations. ${ }^{2}$ By weaving ecologically environmental factors (which are, arguably still feminine) into larger aspects of the international culture and economy, Spivak targets the crucial connection between education and more effective governmental practices. She writes that,

...without an education into epistemic transformation whose most efficient description I happen to find in haq, capital—industrial and finance—cannot be persistently checked and turned around to the interest of the social as practically laid out in the Marxian passage... I am further arguing that this social practice of responsibility based on an imperative imagined as intended from alterity cannot today be related to any named grounding —as in Kant [Emmanuel Kant] or Islam. This is where educating into the planetary imperative-assuming and thus effacing an absolute and discontinuous alterity comfortable with an inexhaustible diversity of epistemes—takes its place. (2012, p. 346)

The transformation to which Spivak refers is not only epistemic, but also liberatory. Pedagogy that ultimately leads to instilling within the next generation a sense of empowerment in holding both state and local government accountable for the resources it provides for its people will sustain not only a higher position within the global economy for countries throughout the Middle East, but also an increased sense of nationalism for the people of Egypt, Tunisia, Syria, Libya, and neighboring countries who have long realized the relationship between education, economy, and democratic rule-at least in its most conservative sense.

\footnotetext{
${ }^{2}$ See from http://www.Un.org/millenniumgoals/2015_MDG_Report.
} 


\section{Conclusion}

In An Aesthetic Education in the Era of Globalization, Gayatri Spivak explores the far-reaching benefits of teaching the humanities as she connects the aesthetics to ecology, politics, an emerging fiscal crisis, cultural capital, and the analytical skills one acquires from studying the humanities. The revolutionary spirit that has spread throughout the Middle East and North Africa will not die with the older members of the Muslim Brotherhood and its allied organizations as long as the younger contingents move forward in restructuring a more stable government based on the sense of citizenship and intellect inspired by the humanities. The quality of life for people who have previously suffered from corrupt governmental practices will continue to improve as long as both formal and informal education includes training in the aesthetics. Spivak pointedly elaborates on this claim by writing,

My desire is to produce problem solvers rather than solve problems, epistemico-epistemological change, in other words. In order to do this, I must continue to teach teachers, current and future, with devotion and concentration, at the schools that produce the "good" rich people (Columbia University) and the beggars... I must understand their desires (not their needs) and, with understanding and love, try to shift them. That is education in the Humanities. (2012, p. 135)

\section{References}

Gelvin, J. (2012). The Arab uprisings: What everyone needs to know. New York: Oxford University Press.

Spivak, G. C. (2012). An aesthetic education in the era of globalization. Cambridge, MA: Harvard University Press. The Millennium Development Goals Report. (2015). New York: A Publication of the United Nations. 